\title{
AN ASSESSMENT OF THE IMPACTS OF THE PENSION SYSTEM REFORMS ON EMPLOYEES' PERFORMANCE AND RETENTION IN NIGERIA DISTILLERIES LIMITED, LAGOS NIGERIA
}

\author{
Samuel Remi and Ajibose Kayode Agbolahan \\ Department of Employment Relations \& Human Resource Management, University of \\ Lagos, Nigeria \\ E-mail: ajibosegbolahan@gmail.com
}

Cite this article:

Samuel R., Ajibose K.A. (2021), An Assessment of the Impacts of the Pension System Reforms on Employees' Performance and Retention in Nigeria Distilleries Limited, Lagos Nigeria. British Journal of Management and Marketing Studies 4(3), 73-86. DOI: 10.52589/BJMMSD9PMGXPY.

\section{Manuscript History \\ Received: 12 July 2021 \\ Accepted: 18 Aug 2021 \\ Published: 9 Sept 2021}

Copyright $(\odot 2020$ The Author(s). This is an Open Access article distributed under the terms of Creative Commons Attribution-NonCommercialNoDerivatives 4.0 International (CC BY-NC-ND 4.0), which permits anyone to share, use, reproduce and redistribute in any medium, provided the original author and source are credited.
ABSTRACT: Consequently, upon many decades of inefficient and corrupt pension management system in Nigeria, public servants in Nigeria dreaded retirement because of the reported plight of retirees who were seen dying on queues or living under the bridges at the Federal Capital City of Abuja. While an average worker in other parts of the world looks forward to a decent and enjoyable post-work life, Nigerians lived in fear of ageing and retirement resulting in several malpractices such as multiple declarations of age with intent to keep them at work far past the official retirement age. Factors arising from pension inadequacies, poor funding, embezzlements and long arrears especially in the public sector led to the initiatives for restructuring of the country's pension system and the enactment of the Pension Reform Act of 2004 and its review Act of 2014. The reforms aimed at making pension administration more effective, efficient, to make and improve on the question of adequacy and fund security. However, key problems in the management of the new pension system involve the perception of the degree and significance of its impact and whether key objectives are satisfied according to the intent of the reforms. This study was designed to examine whether the reforms have contributed significantly to addressing employees' post-work-life concerns and how such assessments impact their performance. Specifically, the paper examines if a relationship exists between the new pension reform act and employee retention, as well as organizational performance using a sample of employees of Nigerian Distilleries Ltd. Three hypotheses were tested at a 0.05 level of significance, using the inferential statistics of Regression Analysis with the aid of Statistical Package for Social Sciences (SPSS version 20). The findings show that there is a significant relationship between the New Pension Reform Act and employee's performance. Also, the New Pension Reform Act has a positive effect on employee retention, compensation design must reflect this option in order to attract, motivate and retain employees. With further evidence that the pension system has the propensity to align the individual and corporate goals by increasing their job commitment, performance and motivation, the paper concludes that proper implementation of the provisions of the pension reform act is a prerequisite for achieving its objectives.

KEYWORDS: Pension Reform Act, Employee Performance, Employee Retention, Compensation Design, Corporate Performance, Nigeria. 


\section{INTRODUCTION}

\section{Background of the Study}

The issue of pensions has received much attention in many countries over the past decade. In recent times, increasingly attracted the attention of policymakers to facilitating privately funded retirement income savings by an ageing workforce (World Bank, 1994). In Nigeria, inadequate and delayed budgetary provisions coupled with poor retirees' welfare system engendered the revision of the public pension system and the unification of the existing pension systems in both the public and private sectors under the Pension Reform Act of 2004 and later amended as the Pension Reform Act of 2014 (Anazodo R.O et' al. 2014).

The dehumanizing suffering of the pensioners has been widely reported in the electronic and print media. Scholarly publications have also focused on the plight of pensioners regarding inadequacy, shoddy and irregular payment of pension entitlements, among other problems [Ogunbameru, 1990; Elumilade, 1999; and Idowu, 2006].

Furthermore, many commentators have observed that much as the reform act in 2004 provided a significant improvement in the pension management system in the country, it was bedevilled by weak controls to prevent mass looting particularly in the public sector, delayed remittances and deductions, poor record-keeping, and many other issues which threatened the efficiency of the schemes. The 2014 Pension Review Act was conceived to strengthen the 2004 Pension Reform Act and block some known loopholes as well as to raise the level of contributions.

\section{Statement of the Research problem}

Over the years, the Nigerian pension system has been fraught or bedevilled with a lot of mismanagement and unscrupulous practices. Pension which guarantees employees a certain level of comfort in their years of retirement has become a source of worry and concern to employees and pensioners in recent times. Life after retirement is one of the dreaded periods for most workers in Nigeria which could lead to psychological and economic problems capable of resulting in low commitment to work and diminish performance (Ogunbamimeru and Bamiwuye, 2004). Consequently, people became sceptical about the long term effectiveness of the pension system to meet the workers expected post-work quality of life. There is, therefore, a question of whether employees will continue to be fully focused on their jobs without fear of unsecured post-work life or that the observed problems with the pension management system will continue to provide substantial distractions to achieve optimal performance effectiveness. This study will among other things assess the impact of the pension system on employee's attitudes, retention and performance.

\section{Objectives of the Study}

The main objective of the study is to examine the effects of the New Pension Reform Act on employee's performance. Other specific objectives are:

- To determine if the new pension reform act influences employee retention in an organization.

- To examine whether the new pension scheme has set out and solved the numerous problems faced by Nigerian employees and pensioners. 
- To determine the differences between the new pension scheme and the old pension scheme.

- To examine the rationale or values and benefits of the new pension scheme to Nigerian employees and pensioners.

- To examine the effectiveness of the pension fund administration in the adoption and implementation of the new pension scheme.

\section{Research Questions}

In this study, an attempt would be made to provide answers to the following questions;

- Does a relationship exist between the new pension reform act and employee's performance?

- Does the new pension reform act influence employee retention?

- Has there been any meaningful improvement in the reform of pension of retirees following the introduction of the reform?

\section{Research Hypotheses}

The following research hypotheses were tested in the study;

$\mathrm{H}_{\mathrm{o} 1}$ : There is no significant relationship between the new pension reform act and employee's performance.

$\mathrm{H}_{02}$ New pension reform act does not influence employee retention.

\section{Significance of the Study}

Given an environment where people are always apprehensive of government initiatives [such as compelling workers to make payments] due to incessant failures and collapse of many public policies, the outcome of this study will help in the assessment of current thinking of employees on how much their expectations have been met and any likely gap in expectations and how the reform systems could benefit all stakeholders. The outcome of such a study would therefore be significant for contributors to the schemes and government as a regulatory agency.

The study would also provide some reference materials for research and policymakers in the evaluation of achievements and lapses in the management and control mechanisms aimed at guaranteeing the success of the schemes as well as identifying critical issues that are likely to threaten its success so as to initiate preventive and remedial actions. It will also supplement the design of some human resource management actions in employee resourcing, performance management and retention. 


\section{LITERATURE REVIEW}

Pension is simply the amount set aside either by an employer or an employee or both to ensure that at retirement, the employee has some regular income to minimize financial dependency and handicaps at old age. It is aimed at providing workers with security by building up plans that are capable of providing guaranteed income to them when they retire or to their dependents when death occurs (Fapohunda, 2013). Robelo (2002) asserted that pension is also the method whereby a person contributes a proportion of his/her earnings during his working life into approved schemes to be assessed after retirement. The contributions provide an income (or pension) on retirement that is treated as earned income. The pension can also be contributed or reserved on behalf of an employee such as in defined schemes. This according to Adams (2005) is the amount paid by the government or company to an employee after working for some specific period of time, considered too old or ill to work or have reached the statutory age of retirement. At the operational level, pension is the monthly sum paid to a retired officer until death because the officer has worked with the organization paying the sum. One can therefore say that pension involves the surrender of part of an employee's current earnings into schemes either voluntarily or obligatorily, jointly funded by the employee and his/her employer or solely by the employee or his employer in order to guarantee continuous regular earning after retirement.

Consequently, since employees' ability to work and continue to earn wages is bound to end one day, the pension system is seen as a generalized concern for everybody. While societies in the West and USA have perfected their systems over many decades, the Nigerian experience is just unfolding from decades of mismanaged schemes under various governments.

A major problem of the pension fund administration in Nigeria was the non-payment or delay in the payment of pension and gratuity by the Federal and State governments (Odia and Okoye, 2012). Animashaun \& Shabi (2008) identified the following problems: the problem of the inherent insecurity of the unfunded state-run pension system which creates anguish, want and penury existence for retirees in their old age; the problem of the harmonization of the public and private pension system; confusion as to the institutional regulator of the scheme; problem of determining the laws that govern the management, control administration and investment of pension funds; bad record-keeping in private and public offices making it impossible to access and quantify the contribution of the individual employee and endemic corruption, among other reasons. For instance, the public sector pension backlog was put at about N2.56 trillion as of December 2005 which became a thorny issue with millions of retired Nigerian workers living in abject poverty, neglected and not properly catered for (Orifowomo, 2006). The pension payment system was also made very complicated and inhuman, requiring very old people to stand in queues for hours inside the sun, frequently resulting in the deaths of retirees due to the stress of the payment conditions. Others include cumbersome clearance procedures, incompetence and inexperience of pension staff added to poor human relations, lack of etiquette and simple courtesy. The Pension Reform Act 2004 which replaced the Pension Act of 1990 established the uniform contributory pension scheme for all employees in public and private sector organizations in Nigeria. The 1990 Act had been the main regulation guiding the operation of pension schemes in Nigeria and despite slight amendments in 1999 and 2000, had remained largely unchanged in form and content. 
The 2004 Act established a new pension scheme that covers all employees in the public service of the federation, the Federal Capital Territory (FCT) and the private sector in Nigeria. Existing pensioners and those who have 3 years or less to retire are exempted from the scheme. The new pension scheme is contributory and expected to be a fully funded system, privately managed and secured by third party custodians of individual accounts. It is further anticipated that everyone who has worked, will receive his/her retirement benefits as at when due. These laudable objectives were not to be trouble-free as the scheme became bedevilled by irregular and/or erratic remittance of deductions by the employers; low level of awareness and understanding about the new scheme by employees; scepticism among the employees about the survival of the scheme; inadequate sanction for defaulting private sectors employers; nonrelease by the pension commission [PENCOM] of guidelines for participation by employees in the informal sector amongst others.

After ten years of the take-off of the unified contributory schemes in Nigeria, the federal government revised the provisions in the Pension Reform Act, 2014. The new Act raised contribution from $15 \%$ [i.e., $7.5 \%$ of annual basic salary each by employers and employees] to $18 \%$ of the enhanced base which includes basic salary, housing and transport allowance with $10 \%$ contribution by employers and $8 \%$ by employees, which will provide additional benefits to workers' Retirement Savings Accounts and thereby enhance their monthly pension benefits at retirement (Tobiloba, 2014:5). Other provisions of the Act include stiffer penalties of not less than ten years imprisonment or five of an amount equal to three times the amount so misappropriated or diverted, or both imprisonment and fine. Ensuring greater protection of pension fund assets has been the core mandate for the National Pension Commission (PenCom) since its formation following the Pension Reform Act (PRA) 2004. The 2014 Pension Act also empowers PenCom to institute criminal proceedings against employers who persistently fail to deduct and/or remit pension contributions of their employees within the stipulated time.

The primary aim of the new scheme is to enable retirees to meet the challenges of retirement. And to ensure the smooth functioning of the scheme in terms of regulation, administration and management.

\section{THEORETICAL FRAMEWORK}

Many theories have been developed in relation to pension reform across the globe such as the utility and preference, life cycle, and productivity theories of pension. This study will adopt the productivity theory as its framework (Dorsey et al.1998)

Productivity theories of pension articulated a dual framework of demand and supply sides. One of the key demand sides of the theory is that pensions are an insurance policy against a number of retirement-age risks, one of which is that a retiree will live longer than expected and their savings will be depleted before death which is solved by early participation in pension contributions. A supply-side perspective states that pension incentives raise workforce productivity and lower labour costs. Both sides of the theory however agreed that pension schemes are established as incentives and motivation to encourage workers to increase their productivity or output or performance. The demand side of the theory posits that employers make payments to employee's pension funds because workers are keen or prefer pension savings to cash payments to their emolument. This is because of the benefits thereof. These 
include reduction in income tax of the employee, the retirement benefits, such as social security from the employer's contributions, interest earnings and dividend earning on pension fund investment or assets that are not taxed.

\section{METHODOLOGY}

\section{Data Collection}

This study adopts a survey method by using designed questionnaires that first seek to establish key respondents background variables such as gender, age, marital status, academic qualifications and management level amongst others. Thereafter, we defined our variables into a Likert scale typology seeking for respondents' agreements on a five [5] agreement scale from strongly disagree to strongly agree. The sampling method adopted was stratified cum random of 103 respondents out of an employee population of 614 from Nigeria Distilleries Limited located at Sango Ota, Ogun State, Nigeria.

\section{Data Analysis}

We also adopted descriptive statistics of percentile for data analysis with regression analysis and analysis of variance [ANOVA] at 95\% confidence level using the statistical Package for Social Sciences-SPSS.

\section{Data Presentation}

We first present the summaries of the background characteristics of the respondents in Table 1 below which shows that the population comprised of $67 \%$ male and $33 \%$ female all ageing below 25 years [24.3\%], 26- 35 years [35.9\%], $36-45$ years [25.2\%] and above 45 years $14.6 \%$.

In terms of educational qualifications, $14.6 \%$ had WASC/SSCE, $29.1 \%$ with National diploma certificates and $36.9 \%$ with first-degree equivalent and $19.4 \%$ have postgraduate degrees. The data further show that $48.5 \%$ were in the junior staff category of management, $38.8 \%$ senior staff and $12.6 \%$ senior management. Those with a length of service below 5 years were $35.9 \%$, $5-10$ years- $43.7 \%$ and $20.4 \%$ had over 10 years of service. 
Table 1. Table showing the background characteristics of Respondents.

\begin{tabular}{|c|c|c|c|c|c|}
\hline & & $\begin{array}{c}\text { Frequency } \\
\mathrm{N}=103\end{array}$ & Percent & $\begin{array}{c}\text { Valid } \\
\text { Percent } \\
\end{array}$ & $\begin{array}{c}\text { Cumulative } \\
\text { Percent } \\
\end{array}$ \\
\hline \multirow{2}{*}{ GENDER } & Male & 69 & 67 & 67 & 67 \\
\hline & Female & 34 & 33 & 33 & 100 \\
\hline \multirow{4}{*}{ AGE } & Below 25 & 25 & 24.3 & 24.3 & 24.3 \\
\hline & $26-35$ years & 37 & 35.9 & 35.9 & 60.2 \\
\hline & $36-45$ years & 26 & 25.2 & 25.2 & 85.4 \\
\hline & Above 45 Years & 15 & 14.6 & 14.6 & 100 \\
\hline \multirow{4}{*}{ MARITAL STATUS } & Single & 40 & 38.8 & 38.8 & 38.8 \\
\hline & Married & 54 & 52.4 & 52.4 & 91.3 \\
\hline & Divorced & 3 & 2.9 & 2.9 & 94.2 \\
\hline & Widow/Widower & 6 & 5.8 & 5.8 & 100 \\
\hline \multirow{4}{*}{ HIGHEST QUALIFICATIONS } & WAEC/EQV & 15 & 14.6 & 14.6 & 14.6 \\
\hline & ND/NCE & 30 & 29.1 & 29.1 & 43.7 \\
\hline & $\mathrm{BSc} / \mathrm{HND}$ & 38 & 36.9 & 36.9 & 80.6 \\
\hline & MBA/MSc & 20 & 19.4 & 19.4 & 100 \\
\hline \multirow{3}{*}{ MANAGEMENT LEVEL } & Junior & 50 & 48.5 & 48.5 & 48.5 \\
\hline & Senior & 40 & 38.8 & 38.8 & 87.4 \\
\hline & Management & 13 & 12.6 & 12.6 & 100 \\
\hline \multirow{3}{*}{ LENGTH OF SERVICE } & Below 5 Years & 37 & 35.9 & 35.9 & 35.9 \\
\hline & $5-10$ years & 45 & 43.7 & 43.7 & 79.6 \\
\hline & Above 10 years & 21 & 20.4 & 20.4 & 100 \\
\hline
\end{tabular}

Source: Study survey analysis

In Table 2 [see appendix 1.] Below we present the respondents' level of agreement to the various pension administration statements. The table shows that while the respondents mostly reflect agreement to seriously agree on most of the dimensions defined in the study, the pattern of responses showed general variances in the agreement levels. Because of this observation, the study went further to assess whether such variances are statistically significant or just by random chances. The data presented in Table 3 show that the observed variances were actually significant along with selected background variables such as gender, education, length of service and management status amongst others at $\mathrm{p}=\leq .05$ 
Table 3. Background variation in the assessment of the variables

Test Statistics

\begin{tabular}{|l|l|r|r|r|r|r|}
\hline & $\begin{array}{l}\text { Analysis of } \\
\text { the } \\
\text { Respondents } \\
\text { by Working } \\
\text { Experience. }\end{array}$ & $\begin{array}{c}\text { Analysis of } \\
\text { the } \\
\text { Respondents } \\
\text { by Sex }\end{array}$ & $\begin{array}{c}\text { Analysis of } \\
\text { the } \\
\text { Respondents } \\
\text { by Age }\end{array}$ & $\begin{array}{c}\text { Analysis of } \\
\text { the } \\
\text { Respondents } \\
\text { by Marital } \\
\text { Status }\end{array}$ & $\begin{array}{c}\text { Analysis of } \\
\text { the } \\
\text { Respondents } \\
\text { by present } \\
\text { position in } \\
\text { the } \\
\text { organization }\end{array}$ & $\begin{array}{c}\text { Analysis of } \\
\text { the } \\
\text { Respondents } \\
\text { by } \\
\text { Educational } \\
\text { Qualification }\end{array}$ \\
\hline $\begin{array}{l}\text { Chi- } \\
\text { Square } \\
\text { Df }\end{array}$ & $8.699^{\mathrm{a}}$ & $11.893^{\mathrm{b}}$ & $9.427^{\mathrm{c}}$ & $74.126^{\mathrm{c}}$ & $21.340^{\mathrm{a}}$ & $12.301^{\mathrm{c}}$ \\
Asymp. & 2 & 1 & 3 & 3 & 2 & 3 \\
Sig. & .013 & .001 & .024 & .000 & .000 & .006 \\
\hline
\end{tabular}

a. 0 cells $(0.0 \%)$ have expected frequencies less than 5. The minimum expected cell frequency is 34.3.

b. 0 cells $(0.0 \%)$ have expected frequencies less than 5 . The minimum expected cell frequency is 51.5 .

c. 0 cells $(0.0 \%)$ have expected frequencies less than 5 . The minimum expected cell frequency is 25.8 .

\section{Test of Research Hypothesis}

The results of the test hypothesis are presented in tables 4, 5, 6 and 7 below.

Ho: There is no significant joint effect of the New Pension Reform Act on Employee's performance.

Table 4. Model Summary

\begin{tabular}{|l|l|l|l|l|}
\hline Model & R & R Square & Adjusted R Square & $\begin{array}{l}\text { Std. Error of the } \\
\text { Estimate }\end{array}$ \\
\hline 1 & $.952^{\mathrm{a}}$ & .905 & .904 & .30189 \\
\hline
\end{tabular}

a. $\quad$ Predictor: (Constant), New Pension Reform Act

b. Dependent variable: Employee's Performance

The table displays R, R squared, adjusted R squared, and the standard error R, the correlation coefficient, is the correlation between the observed and predicted values of the dependent variable. The table shows a positive relationship having an R-value of 0.952 , which means the independent variable is related to employee's performance. There is a significant relationship between the new pension reform act and employee's performance. The Adjusted R square has a value of $90.4 \%$ which indicates that the model truly fit the data well as it measures the proportion of variation in the dependent variable brought about by the action of the independent variable. 
Table 5. ANOVA

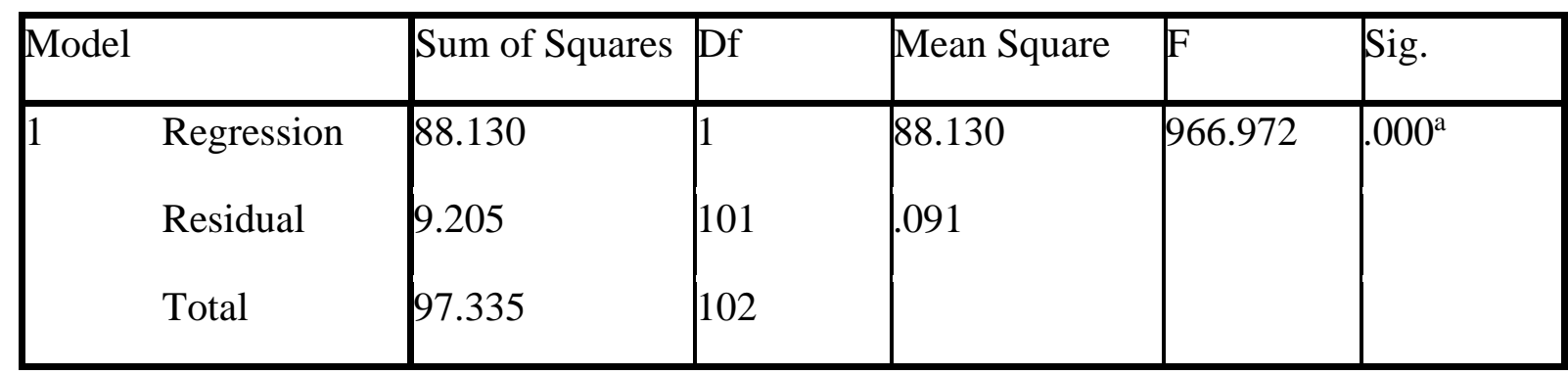

a. Predictor: (Constant), New Pension Reform Act

b. Dependent Variable: Employee's Performance

The independent variable did a good job explaining the variation in the dependent variable with a smaller value less than 0.05 (0.000). Therefore, there is a significant relationship between the new pension reform act and employee's performance. The F ratio value of 966.972 explains that the variation in the dependent variable could not have occurred by chance and as a result of the independent variable.

\section{Hypothesis Two}

$\mathrm{H}_{02}$ : New Pension Reform Act does not influence employee retention

Table 6. Model Summary

\begin{tabular}{|l|l|l|l|l|}
\hline Model & R & R Square & Adjusted R Square & $\begin{array}{l}\text { Std. Error of the } \\
\text { Estimate }\end{array}$ \\
\hline 1 & $939^{\mathrm{a}}$ & .882 & .889 & .31870 \\
\hline
\end{tabular}

a. Predictor: (Constant), New Pension Reform Act

b. Dependent Variable: Employee Retention

The table shows a positive relationship having an R-value of 0.939 , which means the independent variable is related to employee retention. There is a significant relationship between the new pension reform act and employee retention. The Adjusted R square has a value of $88.9 \%$ which indicates that the model truly fits the data well as it measures the proportion of variation in the dependent variable brought about by the action of the independent variable. 
Table 7. ANOVA ${ }^{b}$

\begin{tabular}{|ll|ll|l|l|l|l|}
\hline Model & $\begin{array}{l}\text { Sum } \\
\text { Squares }\end{array}$ & of & Df & Mean Square & F & Sig. \\
\hline 1 & Regression & 76.710 & 1 & 76.710 & 755.258 & $.000^{\mathrm{a}}$ \\
$\begin{array}{l}\text { Residual } \\
\text { Total }\end{array}$ & 10.258 & 101 & .102 & & \\
\hline
\end{tabular}

a. Predictor: (Constant), New Pension Reform Act

b. Dependent Variable: Employee Retention

The output for regression displays information about the variation accounted for by the model. The independent variable did a good job explaining the variation in the dependent variable with a smaller value less than $0.05(0.000)$. Therefore, there is a significant relationship between the new pension reform act and employee retention. The $F$ ratio value of 755.258 explains that the variation in the dependent variable could not have occurred by chance and as a result of the independent variable.

\section{DISCUSSION OF FINDINGS}

This study data shows that there is a relationship between the new pension reform act and employee's performance at a statistical level of significance. While this information is important for human resource management intervention strategies in performance management, there is evidence of variances based on employees' backgrounds. For example, males show a higher level of expectation about the positive effect of the pension reform [Mean 3.36] than females [Mean 1.80], males also expressed a higher level of positive relationship between the pension reform act and employee performance; retention and organizational effectiveness at Sig $\leq .001$ [as shown in appendix II]. This evidence also agrees with Sule and Enzugwi (2009), who assert that the new pension scheme guarantees employee's comfort and commitment to the organization during his/her active years. The study revealed that workers are likely to be more committed to their duties since the introduction of the contributory pension scheme in Nigeria.

Furthermore, while Wysocki \& Kepner, (2009) argued that there is a relationship between the pension systems and employee retention, this study result shows that such relationship is actually at the level of statistical significance which likely precludes a random event. This will be significant for human resource management in the design of compensation and benefits packages to enhance not only attraction but also performance and retention. On this basis, the study agrees with Onyene (2001), Akingbade (2006), Ushie, Agba and Best (2010), Agba and Ushie (2010), who all posits that the movement of workers from one job to the other in Nigeria is not unconnected with payment of benefits including pension and retirement. 


\section{CONCLUSIONS}

The study has shown that the new pension system in the country has a positive effect on employee's performance, retention and is strategic to organizational performance. While the pension system may not be the sole determinant of employee retention and performance, its moderating effect may be significant and should attract greater attention in compensation design. Losing strategic employees due to inducement on pension payments by competitors may likely involve some cost implications in attraction, recruitment, training, wastage of time of the internal trainer, the risk of cultural and organization-person misfit, the risk of divulging strategic information of the company to the competitor by the exited staff, the risk of losing clients that are associated or psychologically attached to the exited staff and so on. Consequently, the new pension reform act must be properly implemented and must not be toiled with if an organization is to attain corporate and employee objectives. As Table 2 in the appendix shows, $77 \%$ of respondents strongly agree to remain with an employer that meets the pension contribution systems while $92 \%$ show on the contrary that defaulting organisations are likely to suffer employee turnover. Compensation managers will therefore be well informed based on this outcome to give premium attention to pension in the process of compensation negotiations.

Finally, the size and scope of this study will most likely affect the generalizability of the findings. There is generally more room for expanded study to assess whether the new pension reform act actually has such wide implications for employee retention and performance. Particularly, what are the long-term effects of the employee control system of the pension account in maintaining loyalty and long-term commitment to a single employer? With the assumption that the pension act is gratuity inclusive, will employees continue to be motivated to serve minimum years such as required to earn terminal benefits?

\section{RECOMMENDATION}

Recommendations can therefore be summarized as follow:

1. Government should put strict measures in place to ensure the proper monitoring and implementation of the provision of the Pension Reform Act of 2014.

2. Workers and employers of labour should be properly enlightened on the benefits of the contributory pension scheme. This would further ensure worker confidence towards retirement.

3. Workers should be given freedom to choose pension fund Administrator (PFA) of their choice.

4. Pre-retirement enlightenment workshops should be organized for workers who are about to retire.

5. Pension scheme policy should be written clearly in the Employee manual book.

6. Finally, compensation managers need to be innovative in the design and negotiation of compensation packages and be sensitive to issues raised by the employees' background variations such as gender, education and length of service. 


\section{REFERENCES}

Animasahun and Shabi (2009), Fundamentals of Industrial Relations: Issues and Theories, Hybrid Consult Publisher, Lagos.

Anozodo R.0 et'al (2014), "The effect of New Pension Pension Scheme on Retirees in Nigeria: 2004-2014,” In Review of Public Administration and Management, Vol 3, No.6, pp. 180-190

Dorsey, S., Cornwell, C., \& Macpherson, D., (1998) Pensions and productivity, W.E., Upjohn Institute for Employment Research, Kalamazoo,Michigan.

Fapohunda T.M (2013): "The Pension System and Retirement Planning in Nigeria”, Mediterranean Journal of Social Sciences, Vol 4 No 2.

Finance and Banking Research,4(4), 48 -58.

Herskovit S.J. (2007), "Nigeria's Rigged Democracy, Foreign Affairs 86(4): 115-300.

Odia, J.O. and Okoye, A.E. (2012). "Pension Reform in Nigeria: A Comparison Between the Oldand New Scheme". In Afro Asian Journal of Social Sciences, Vol. 3 No. 3 pp. 1-17

Ogunbameru, O. \&Bamiwuye, S. (2004). Attitude Towards Retirement and Pre Retirement Education Among Nigerian Bank Workers.Education Gerontology, 30 (5), 391-401.

Ogunbameru, O. A. (1999). Personal retirement planning in Nigeria: A study of Lagos state civil servants. IFE Social Sciences Review, 16 (1), 50-57.

Ohai, C. and Awoyinfa, S. (2013). Fear, Suspicion still surround Pension Scheme retrieve from www.punchng.com/feature/ fear-suspicion-still-surround-pension scheme

Omoni, G.E. (2013), "An Overview of the New Pension Scheme and Teachers' Level of Awareness in Delta State of Nigeria: Counselling Implications", InAfrican Journal of Social Sciences. Vol. 3. No. 3 pp. 53-63.

Onyene, V.E. (2001). Issues in Incentive administration for Effective Workforce Retention: A Study of SomePrimary School Teachers in Aguata. In N.A. Nwagwu, E.T. Eliametator, M.A. Oguna\& M. Nwadiani (ed.), Current Issues in Educational Management in Nigeria (176-188)

Orifowomo, O.A. (2006): A Critical Appraisal of Pension System Reforms in Nigeria. 10 GON Z.J.INT'L 1 available at http://www.gonzagajil.org.

PenCom (2014), Pension Reform Act 2014: available at http://www.pencom.gov.ng/download/Pension\%20Laws/Pension\%20Reform\%20Act\% 202014.pdf

Pension Reform Act (2004), http://www.pencom.gov.ng/download/Nigeria-

PensionReformAct2004.pdf

Robelo, M.K. (2002) Comparative Regulation of Private Pension Plans, Frabetoefgvsp.br.

Sule, K.O. and Ezugwu, C.I. (2009), "Scheme on Employee Retirement Benefits of Quoted Firms in Nigeria "African Journal of Accounting, Economics, F

Tobiloba, A. (2014), "The New Pension Act 2014: Hope for the Nigerian Employee", Daily Independent, Tuesday, July 8, Pp. 14-15.

Ushie, E.M., Agba, A.M.O., Agba, M.S. \& Best, E.G. (2010). Supplementary Livelihood Strategies among Workers in Nigeria: Implications for Organizational Growth and Effectiveness. International Journals of Business and Management, 5 (3), 146-154.

World Bank (1994) Averting the old age crisis: Policies to protect the old and promoted growth. Oxford University Press. 
British Journal of Management and Marketing Studies

ISSN: 2689-5072

Volume 4, Issue 3, 2021 (pp. 73-86)

www.abjournals.org

\section{APPENDIX 1}

Table 2: Showing the distribution of responses to the study questions on the assessment of the new pension reform system.

\begin{tabular}{|c|c|c|c|c|c|}
\hline & \multicolumn{5}{|c|}{ Distribution of Responses $N[\%]$} \\
\hline Respondent Questions & $\mathrm{SD}$ & D & A & SA & $\begin{array}{l}\text { CUM } \\
n[\%]\end{array}$ \\
\hline $\begin{array}{l}\text { The } 2014 \text { Pension Reform Act in Nigeria is more effective than } \\
\text { the old ones. }\end{array}$ & $10[9.7 \%]$ & $13[12.6 \%]$ & $42[40.8 \%]$ & $38[36.9 \%]$ & $103[100 \%]$ \\
\hline $\begin{array}{l}\text { The provisions of the } 2014 \text { Act have adequ ately gu arantee } \\
\text { employees certain level of comfort in their years of retirement }\end{array}$ & $14[13.6 \%]$ & $20[19.4 \%]$ & $29[28.2 \%]$ & $40[38.8 \%]$ & $103[100 \%]$ \\
\hline $\begin{array}{l}\text { The new pension scheme may en hance employee's } \\
\text { commitment to work. }\end{array}$ & $13[12.6 \%]$ & $18[17.5 \%]$ & $34[33.0 \%]$ & $38[36.9 \%]$ & $103[100 \%]$ \\
\hline $\begin{array}{l}\text { There is tendency for my performance to improve in this } \\
\text { organization if my retirement ben efits are gu aranteed. }\end{array}$ & $20[19.4 \%]$ & $17[16.5 \%]$ & $32[31.1 \%]$ & $34[33.0 \%]$ & $103[100 \%]$ \\
\hline $\begin{array}{l}\text { Organizations that implement new pension reform act attracts } \\
\text { talent. }\end{array}$ & $6[5.8 \%]$ & $25[24.3 \%]$ & $40[38.8 \%]$ & $32[31.1 \%]$ & $103[100 \%]$ \\
\hline $\begin{array}{l}\text { The new pension reform act may have positive effects on } \\
\text { empl oyee's attitu de to work }\end{array}$ & $11[10.7 \%]$ & $12[11.7 \%]$ & $31[30.1 \%]$ & $49[47.6 \%]$ & $103[100 \%]$ \\
\hline $\begin{array}{l}\text { The contributory pension scheme may increase work er's } \\
\text { performance }\end{array}$ & $23[22.3 \%]$ & $10[9.7 \%]$ & $39[37.9 \%]$ & $31[30.1 \%$ & $103[100 \%]$ \\
\hline $\begin{array}{l}\text { I may stay long in this organization if my employer remits my } \\
\text { pension contribution as at when due }\end{array}$ & $13[12.6 \%]$ & $9[8.7 \%]$ & $37[35.9 \%]$ & $44[42.7 \%]$ & $103[100 \%]$ \\
\hline $\begin{array}{l}\text { Payment risk associated with liquidity, ill-health or death of } \\
\text { employer may not occur in the new pen sion scheme }\end{array}$ & $4[3.9 \%]$ & $9[8.7 \%]$ & $52[50.5 \%]$ & $38[36.9 \%]$ & $103[100 \%]$ \\
\hline $\begin{array}{l}\text { The new pension scheme has set out to solve the numerous } \\
\text { problems faced by employees and retirees in the past }\end{array}$ & $23[22.3 \%]$ & $10[9.7 \%]$ & $31[30.1 \%]$ & $39[37.9 \%]$ & 103 [100\%] \\
\hline $\begin{array}{l}\text { My Motivation to work hard for the organization may lik ely to } \\
\text { improve with the new pensi on reform act. }\end{array}$ & $8[7.8 \%]$ & $18[17.5 \%]$ & $44[42.7 \%]$ & $33[32 \%]$ & 103 [100\%] \\
\hline $\begin{array}{l}\text { The new pension scheme may improve the standard of living } \\
\text { of retirees. }\end{array}$ & $30[29.1 \%]$ & 31 [30.1\%] & $22[21.4 \%]$ & $20[19.4 \%]$ & 103 [100\%] \\
\hline $\begin{array}{l}\text { Organizations that are not implementing new pension reform } \\
\text { act are likely to su fer employee turnover. }\end{array}$ & $4[3.9 \%]$ & $4[3.9 \%]$ & 41 [39.8\%] & $52[52.4 \%]$ & $103[100 \%]$ \\
\hline $\begin{array}{l}\text { The new pension scheme may have positive effect on } \\
\text { productivity of employees. }\end{array}$ & $10[9.7 \%]$ & 19 [18.4\%] & 36 [35\%] & $38[36.9 \%]$ & $103[100 \%]$ \\
\hline $\begin{array}{l}\text { The new contributory pension scheme may increase my loyalty } \\
\text { to my organization. }\end{array}$ & $12[11.7 \%]$ & $22[21.4 \%]$ & 40 [38.8\%] & 29 [28.2\%] & 103 [100\%] \\
\hline $\begin{array}{l}\text { The pension fund administrators are effective in performing } \\
\text { their duties }\end{array}$ & $18[17.5 \%]$ & $28[27.2 \%]$ & 27 [26.2\%] & $30[29.1 \%]$ & 103 [100\%] \\
\hline $\begin{array}{l}\text { The new pension scheme may have positive effect on employee } \\
\text { retention. }\end{array}$ & $22[21.4 \%]$ & 21 [20.4\%] & 25 [24.3\%] & 35 [34\%] & 103 [100\%] \\
\hline $\begin{array}{l}\text { With this new pension act, employees are ready to work hard } \\
\text { to earn pay rise that will enrich their Retirement Saving } \\
\text { Accounts (RSAs) }\end{array}$ & $10[9.7 \%]$ & $17[16.5 \%]$ & 37 [35.9\%] & 39 [37.9\%] & 103 [100\%] \\
\hline $\begin{array}{l}\text { Organizations' productivity may improve with this new } \\
\text { pension scheme. }\end{array}$ & $8[7.8 \%]$ & $17[16.5 \%]$ & 36 [35\%] & $42[40.8 \%]$ & 103 [100\%] \\
\hline $\begin{array}{l}\text { Employes post work li fe fears are significantly redu ced by the } \\
\text { new pension reform act of } 2014 \text {. }\end{array}$ & $22[21.4 \%]$ & $10[9.7 \%]$ & $32[31.1 \%]$ & $39[37.9 \%]$ & 103 [100\%] \\
\hline $\begin{array}{l}\text { The new pension reform act may lead to employee's job } \\
\text { satisfaction }\end{array}$ & $13[12.6 \%]$ & $11[10.7 \%]$ & 49 [47.6\%] & $30[29.1 \%]$ & 103 [100\%] \\
\hline $\begin{array}{l}\text { With the introdu ction of new pension reform act, the monthly } \\
\text { pension should be able to cater for my basic needs (food, } \\
\text { housing and shelter) after retirement. }\end{array}$ & $4[3.9 \%]$ & $6[5.8 \%]$ & 51 [49.5\%] & $42[40.8 \%]$ & 103 [100\%] \\
\hline $\begin{array}{l}\text { The percentage of monthly contributions to my retirement } \\
\text { account at } 18 \% \text { should be able to adequ ately catered for my } \\
\text { old age. }\end{array}$ & 25 [24.3\%] & $43[41.7 \%]$ & 19 [18.4\%] & $16[15.5 \%]$ & 103 [100\%] \\
\hline My standard of living will be reduced after retirement. & $24[23.3 \%]$ & $37[35.9 \%]$ & $30[29.1 \%]$ & $12[11.7 \%]$ & $103[100 \%]$ \\
\hline
\end{tabular}


British Journal of Management and Marketing Studies

ISSN: 2689-5072

Volume 4, Issue 3, 2021 (pp. 73-86)

www.abjournals.org

APPENDIX II. ONE WAY ANALYSIS OF GENDER EFFECT ON PERCEPTION OF THE PENSION REFORM ACT.

\begin{tabular}{|c|c|c|c|c|c|c|c|c|c|c|c|c|c|c|c|}
\hline \multirow{3}{*}{\multicolumn{2}{|c|}{$\begin{array}{l}\text { Gender resonse on the impacts of the } \\
\text { new ension system on key emloyment } \\
\text { relationship factors }\end{array}$}} & \multicolumn{14}{|c|}{ Descriptives } \\
\hline & & \multirow[b]{2}{*}{$N$} & \multirow[b]{2}{*}{ Mean } & \multirow[b]{2}{*}{$\begin{array}{l}\text { Std. } \\
\text { Dev }\end{array}$} & \multirow[b]{2}{*}{$\begin{array}{l}\text { Std. } \\
\text { Error }\end{array}$} & \multicolumn{2}{|c|}{ Interval for Mean } & \multirow[b]{2}{*}{ Min } & \multirow[b]{2}{*}{ Max } & \multicolumn{6}{|c|}{ ANOVA } \\
\hline & & & & & & $\begin{array}{l}\text { Lower } \\
\text { Bound }\end{array}$ & $\begin{array}{l}\text { Upper } \\
\text { Bound }\end{array}$ & & & & $\begin{array}{l}\text { Sum of } \\
\text { Squares }\end{array}$ & df & $\begin{array}{l}\text { Mean } \\
\text { Square }\end{array}$ & $\mathrm{F}$ & Sig. \\
\hline \multirow[t]{3}{*}{$\begin{array}{l}\text { New Pension Reform } \\
\text { Act }\end{array}$} & Male & 69 & 3.37 & 0.52 & 0.06 & 3.24 & 3.49 & 2.64 & 4.00 & $\begin{array}{l}\text { Between } \\
\text { Groups }\end{array}$ & 55.437 & 1 & 55.44 & 153.47 & .000 \\
\hline & Female & 34 & 1.81 & 0.73 & 0.13 & 1.55 & 2.06 & 1.00 & 5.00 & $\begin{array}{l}\text { Within } \\
\text { Groups }\end{array}$ & 36.483 & 101 & 0.36 & & \\
\hline & Total & 103 & 2.85 & 0.95 & 0.09 & 2.67 & 3.04 & 1.00 & 5.00 & Total & 91.919 & 102 & & & \\
\hline \multirow[t]{3}{*}{ Employee Performance } & Male & 69 & 3.52 & 0.46 & 0.06 & 3.41 & 3.63 & 2.88 & 4.00 & $\begin{array}{l}\text { Between } \\
\text { Groups }\end{array}$ & 70.166 & 1 & 70.17 & 260.84 & .000 \\
\hline & Female & 34 & 1.77 & 0.62 & 0.11 & 1.55 & 1.98 & 1.00 & 2.88 & $\begin{array}{l}\text { Within } \\
\text { Groups }\end{array}$ & 27.169 & 101 & 0.27 & & \\
\hline & Total & 103 & 2.94 & 0.98 & 0.10 & 2.75 & 3.14 & 1.00 & 4.00 & Total & 97.335 & 102 & & & \\
\hline \multirow[t]{3}{*}{ Employee Retention } & Male & 69 & 3.60 & 0.49 & 0.06 & 3.48 & 3.72 & 2.67 & 4.00 & $\begin{array}{l}\text { Between } \\
\text { Groups }\end{array}$ & 58.954 & 1 & 58.95 & 212.55 & .000 \\
\hline & Female & 34 & 1.99 & 0.59 & 0.10 & 1.78 & 2.20 & 1.00 & 2.67 & $\begin{array}{l}\text { Within } \\
\text { Groups }\end{array}$ & 28.014 & 101 & 0.28 & & \\
\hline & Total & 103 & 3.07 & 0.92 & 0.09 & 2.89 & 3.25 & 1.00 & 4.00 & Total & 86.969 & 102 & & & \\
\hline \multirow[t]{3}{*}{$\begin{array}{l}\text { Organizational } \\
\text { Performance }\end{array}$} & Male & 69 & 3.50 & 0.46 & 0.06 & 3.39 & 3.61 & 3.00 & 4.00 & \begin{tabular}{|l|} 
Between \\
Groups
\end{tabular} & 60.875 & 1 & 60.88 & 266.70 & .000 \\
\hline & \begin{tabular}{|l|} 
Female \\
\end{tabular} & 34 & 1.86 & 0.51 & 0.09 & 1.68 & 2.04 & 1.00 & 2.67 & $\begin{array}{l}\text { Within } \\
\text { Groups }\end{array}$ & 23.054 & 101 & 0.23 & & \\
\hline & Total & 103 & 2.96 & 0.91 & 0.09 & 2.78 & 3.14 & 1.00 & 4.00 & Total & 83.929 & 102 & & & \\
\hline
\end{tabular}

